\title{
Micropropagation protocol for the wild Brazilian greenberry (Rubus erythroclados)
}

\section{Protocolo de micropropagación de mora-verde (Rubus erythroclados) nativa del Brasil}
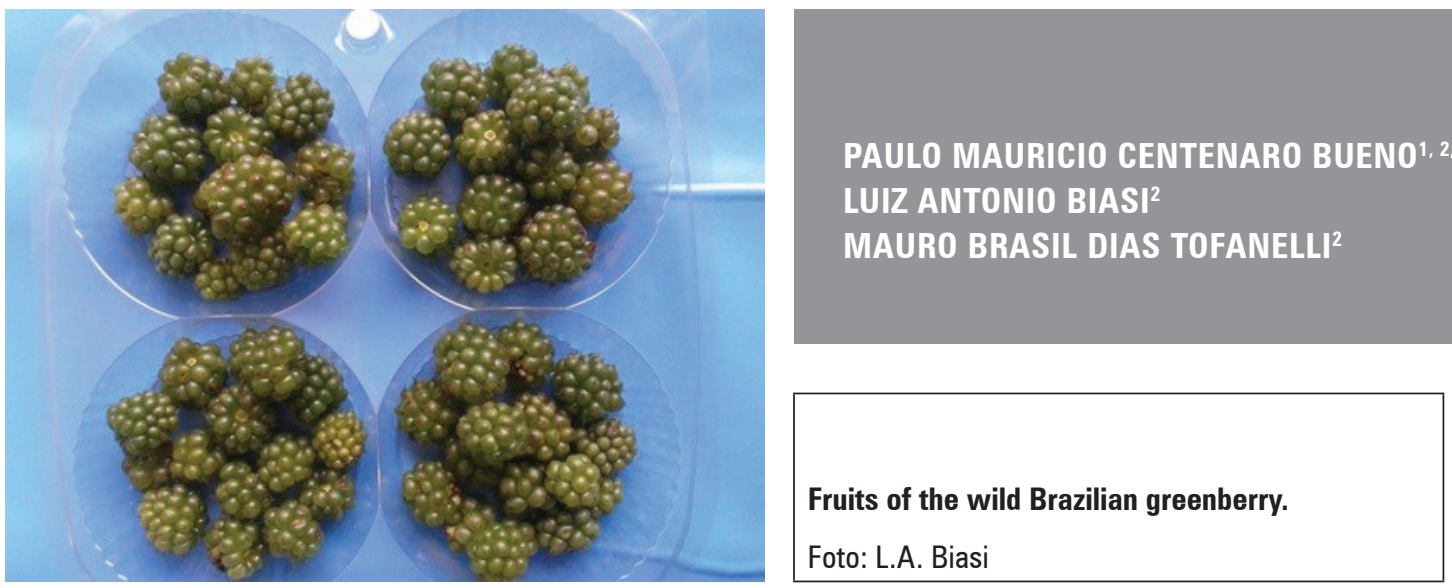

\begin{abstract}
This study presents the first micropropagation protocol for greenberry (Rubus erythroclados), a wild Brazilian species with edible green fruits. In the in vitro multiplication stage, three concentrations of benzyladenine (BA) were tested $(0,5$ and $10 \mu \mathrm{M})$, combined with three concentrations of indolebutyric acid (IBA) $(0,3$ and $6 \mu \mathrm{M})$ in two subsequent subcultures. In the rooting stage, in and ex vitro rooting were compared after pulse treatment of the microcutting for 10 seconds in IBA $(0,2.46,4.92$ and $7.38 \mathrm{mM})$. For the in vitro trial, the microcuttings were maintained in glass bottles with an MS medium under controlled conditions inside a growth room. For the ex vitro trial, the microcuttings were planted in styrofoam containers with vermiculite and maintained inside a greenhouse with an intermittent mist system. $R$. erythroclados multiplication was obtained with the addition of BA to the culture medium, while IBA reduced the shoot proliferation and increased mortality. The ex vitro rooting showed the best results, reaching $95.8 \%$ for rooted and acclimatizated plants without IBA. An efficient and simple protocol can be used for $R$. erythroclados micropropagation with $5 \mu \mathrm{M} \mathrm{BA}$ for in vitro shoot proliferation and ex vitro rooting of microcuttings with intermittent misting.
\end{abstract}

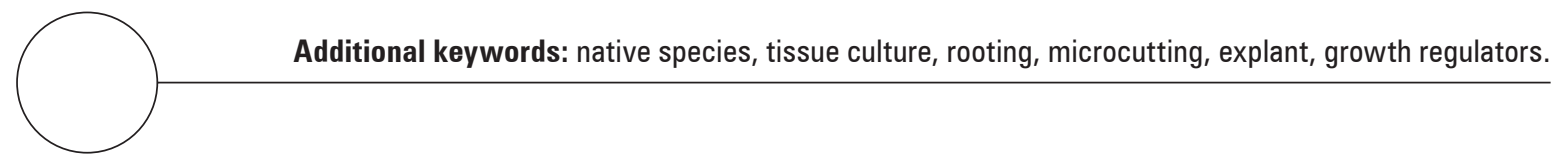

Campus Palmas, Instituto Federal do Paraná, Palmas-PR (Brazil). ORCID Bueno, P.M.C.: 0000-0002-6066-9131

Departamento de Fitotecnia e Fitossanitarismo, Universidade Federal do Paraná, Curitiba-PR (Brazil). ORCID Biasi, L.A.: 0000-0002-3479-8925; ORCID Tofanelli, M.B.D.: 0000-0002-1831-3326

3 Corresponding author. paulo.bueno@ifpr.edu.br 


\section{RESUMEN}

El presente trabajo presenta el primer protocolo de micropropagación de morera verde (Rubus erythroclados), una especie fructífera nativa de Brasil. En la fase de multiplicación in vitro, se probaron tres concentraciones de benziladenina (BA) (0, 5 y $10 \mu \mathrm{M})$ combinadas con tres concentraciones de ácido indolbutírico (IBA) (0, 3 y $6 \mu \mathrm{M})$ en dos cultivos subsiguientes. En la etapa de enraizamiento, el enraizamiento in y ex vitro fue comparado después del tratamiento de inmersión rápida de las microestacas durante 10 segundos en solución de IBA (0;2,46; 4,92 y 7,38 $\mathrm{mM}$ ). Para el experimento in vitro, las microestacas se mantuvieron en recipientes de vidrio con medio de cultivo $\mathrm{MS}$ en una sala de crecimiento con condiciones de temperaturas controladas. Para el experimento ex vitro, las microestacas fueron plantadas en bandejas de poliestireno expandido con vermiculita, y se mantuvieron en una casa de vegetación con sistema de nebulización intermitente. La multiplicación de $R$. erythroclados fue obtenida con la adición de BA en el medio de cultivo, mientras que IBA redujo la emisión de brotes y aumentó la mortalidad de explantes. El enraizamiento ex vitro mostró los mejores resultados, llegando al 95,8\% de microestacas enraizadas y aclimatadas sin tratamiento con IBA. Un protocolo simple y eficiente puede ser utilizado para la micropropagación de $R$. erythroclados con $5 \mu \mathrm{M}$ de BA para multiplicación in vitro y enraizamiento de microestacas ex vitro en sistema de nebulización intermitente.

Palabras clave adicionales: especie nativa, cultivo de tejidos, enraizamiento, microestaca, explante, reguladores de crecimiento. regulators.

Received for publication: 20-12-2017 Accepted for publication: 30-05-2018
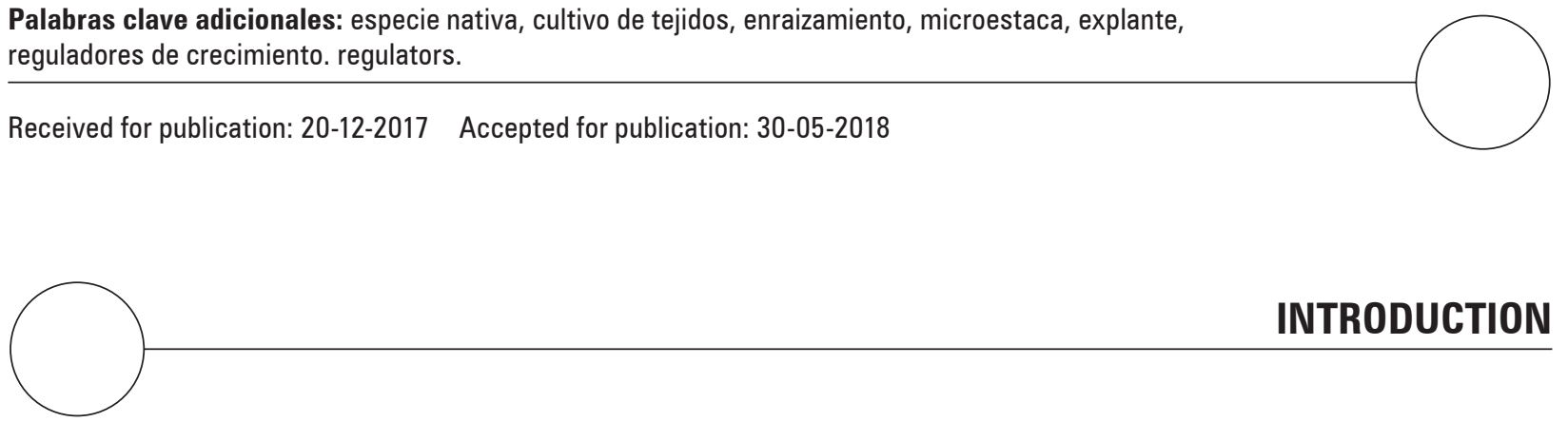

The greenberry (Rubus erythroclados) is a native plant from grassy regions and rain forests in southern Brazil (Cordeiro et al., 2011). Its green fruits (Fig. 1A and 1B), with high sugar levels and a pleasant taste, drew the attention of the local population, revealing their marketing potential alongside other small fruits. However, the cuttings of this species are difficult to root, and there is a lack of published studies on its propagation; so, this in vitro research was carried out.

Blackberry plants (Rubus spp.) can be propagated with root cuttings, stem cuttings (Maia and Botelho, 2008; Campagnolo and Pio, 2012) and tissue cultures (Pasa et al., 2012), of which tissue cultures are the surest way to avoid contamination by fungi, bacteria, viruses and nematodes in addition to resulting in genetically uniform plants in a short period of time. However, the great variability in the in vitro behavior requires us to develop specific growing conditions since not all Rubus species have a high potential for in vitro propagation (Debnath, 2003). For each species and cultivar, there is a specific culture medium, and, to determine which is the best, several tests should be performed.
The plant growth regulators used in blackberry tissue cultures include benzyladenine (BA) and indolebutyric acid (IBA) (Lazic and Ruzic, 2007). The rooting of microcuttings can either be performed in vitro, as is already widely used (Deng and Donnelly, 1993) or ex vitro during acclimatization, directly on the substrate (Jin et al., 1992; Augusto et al., 2006) or in float hydroculture (Clapa et al., 2013). Ex vitro rooting offers the advantage of reducing difficulties related to survival and development of plants cultivated in vitro (Augusto et al., 2006; Pelizza et al., 2013) and also reduces costs.

The aim of this study was to establish a useful and simple greenberry micropropagation protocol with satisfactory multiplication, rooting and acclimatization rates.

\section{MATERIAL AND METHODS}

The initial explants were collected from mother plants growing into a greenhouse (Fig. 1C). Nodal segments (Fig. 1D) from new shoots were disinfected and established in vitro. The explants for this 
study were derived from the multiplication stage after three subcultures in vitro with $5 \mu \mathrm{M} \mathrm{BA}$, and, to completely eliminate the effects of this growth regulator, the explants were submitted to two subcultures in an MS medium free of plant growth regulators. Each explant was composed of a lateral bud with a pair of leaves. The plants were maintained in a growth room at $25 \pm 2^{\circ} \mathrm{C}$ with a 16 -h photoperiod and $20 \mu \mathrm{mol} \mathrm{m} \mathrm{m}^{-2} \mathrm{~s}^{-1}$ irradiance provided by cool-white fluorescent bulbs.

An MS culture medium was used (Murashige and Skoog, 1962) supplemented with $30 \mathrm{~g} \mathrm{~L}^{-1}$ sucrose. The $\mathrm{pH}$ of the solution was adjusted to 5.8 using $0.1 \mathrm{~N}$ sodium hydroxide before the addition of $6 \mathrm{~g} \mathrm{~L}^{-1}$ agar and sterilization with autoclaving at $120^{\circ} \mathrm{C}$ and a pressure of $1.5 \mathrm{~atm}$ for $20 \mathrm{~min}$. $30 \mathrm{~mL}$ of the culture medium were placed in glass bottles, which were sealed with a polypropylene cap and plastic film.

In the trial for multiplication, the experiment design was completely randomized in a factorial arrangement $(3 \times 3)$, with three IBA concentrations $(0,3$ and $6 \mu \mathrm{M})$, three BA concentrations $(0,5$ and $10 \mu \mathrm{M})$, four replications, 12 plants per experiment plot, and six microcuttings per bottle. This experiment was evaluated for two subcultures, and the explants of each treatment were used in the following treatment after 2 months of culture.
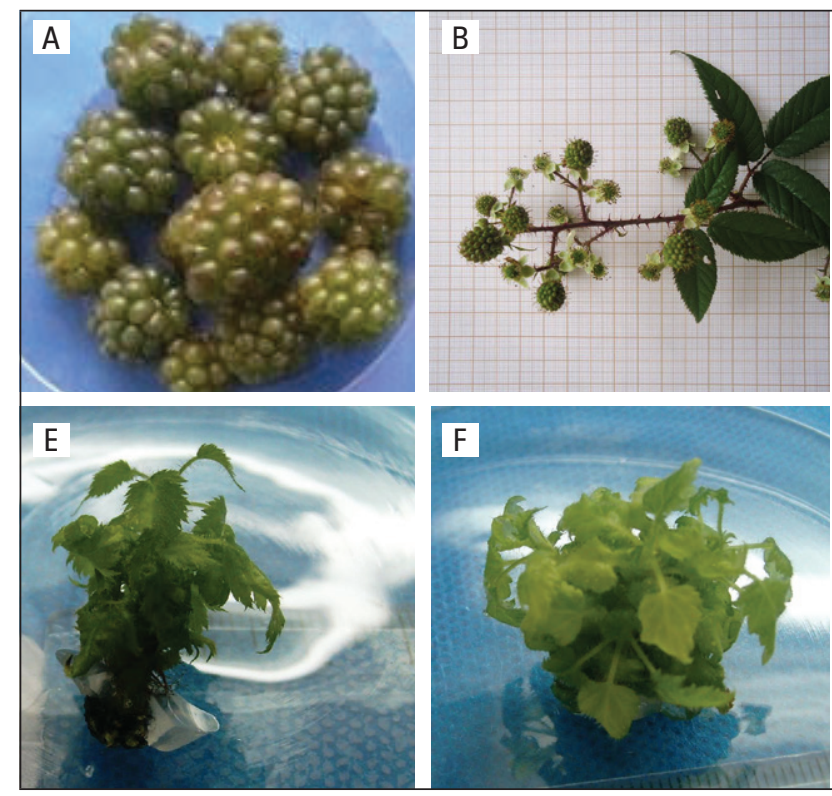

The analyzed parameters included the number of new shoots per explant with at least $0.3 \mathrm{~cm}$, the largest shoot height, the number of new leaves per shoot and roots per explant, the percentage of dead explants, the hyperhydricity, the explants with callus formation, and the rooted explants.

The rooting trials were conducted with a completely randomized design in a factorial arrangement $(4 \times 2)$, with four IBA concentrations $(0,2.46,4.92$ and 7.38 $\mathrm{mM}$ ), two environments (in and ex vitro), four replications and 12 plants per experiment plot. The culture medium and growth room for the in vitro conditions were the same as those used in the multiplication trial. For the ex vitro rooting, microcuttings were placed in styrofoam containers with vermiculite in a greenhouse with an intermittent mist system.

For these trials, the microcuttings were cultivated in a culture medium containing $5 \mu \mathrm{M} \mathrm{BA}$, and, to eliminate the effects of the plant growth regulator, they were submitted to two subcultures with an MS medium free of plant growth regulators.

Each microcutting was held with four leaves and about $1 \mathrm{~cm}$ in height. The base of each microcutting was placed into the respective IBA solution for ten seconds and then placed in vitro or ex vitro. The IBA
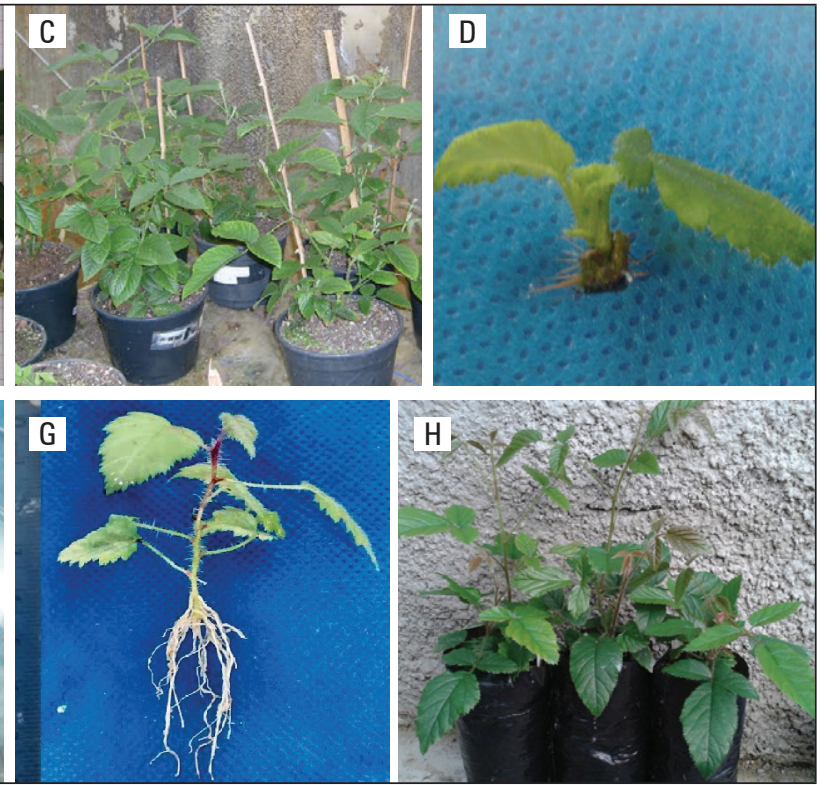

\footnotetext{
Figure 1. Aspects of Rubus erythroclados. A. Ripe fruits; B. Branch with apical inflorescences and immature fruits; C. Mother
plants in a greenhouse; D. Nodal segment with new shoot in vitro; E. Shoot proliferation in the first subculture with
$5 \mu \mathrm{M}$ BA; F. Shoot proliferation in the second subculture with $5 \mu \mathrm{M}$ BA; G. Plant rooted ex vitro without a growth

Figure 1. Aspects of Rubus erythroclados. A. Ripe fruits; B. Branch with apical inflorescences and immature fruits; C. Mother
plants in a greenhouse; D. Nodal segment with new shoot in vitro; E. Shoot proliferation in the first subculture with
$5 \mu \mathrm{M}$ BA; F. Shoot proliferation in the second subculture with $5 \mu \mathrm{M}$ BA; G. Plant rooted ex vitro without a growth

Figure 1. Aspects of Rubus erythroclados. A. Ripe fruits; B. Branch with apical inflorescences and immature fruits; C. Mother
plants in a greenhouse; D. Nodal segment with new shoot in vitro; E. Shoot proliferation in the first subculture with
$5 \mu \mathrm{M}$ BA; F. Shoot proliferation in the second subculture with $5 \mu \mathrm{M}$ BA; G. Plant rooted ex vitro without a growth regulator; H. Acclimatized plants.
} 
was diluted with two different methods using an ethanol solution $(50 \% \mathrm{v} / \mathrm{v})$ and some drops of $1 \mathrm{~N}$ $\mathrm{NaOH}$. The solution $\mathrm{pH}$ was adjusted to 7.0 in both methods.

These trials were evaluated after $69 \mathrm{~d}$, and the following parameters were analyzed: percentage of rooted microcuttings, dead microcuttings, and microcuttings with a callus (including those rooted), number of roots and leaves per plant, length of the largest root, and plant growth.

The data were submitted to Bartlett's test to check for homogeneity in the variances and analyzed following Analysis of Variance (ANOVA). The means were compared by using the Tukey test with Sisvar ${ }^{\circledR}$ statistical program. The differences between the means were significant with a probability of $P \leq 0.05$.

\section{RESULTS AND DISCUSSION}

\section{Multiplication}

The use of $5 \mu \mathrm{M}$ BA was sufficient to obtain one of the higher multiplication rates (Fig. $1 \mathrm{E}$ and $1 \mathrm{~F}$ ), 4.6 and 4.1 for first and second subculture, respectively, without a statistical difference $(P>0.05)$ from 10 $\mu \mathrm{M}$ BA. Whereas, in its absence, multiplication did not occur. The use of IBA is dispensable for multiplication although its presence significantly decreases hyperhydricity. These responses were observed in either the first (Tab. 1) and second subculture (Tab. 2). Debnath (2004) also observed only one shoot formation per explant in a culture medium free of cytokines when multiplying the dwarf raspberry (Rubus pubescens); this number increased with the addition of BA. Erig et al. (2002) reported that $5.1 \mu \mathrm{M} \mathrm{BA}$ promoted the highest multiplication rate of blackberry cv. Tupy, which can be multiplied in vitro without the addition of IBA in the culture medium, as observed in this study. A commercial micropropagation protocol using $3.56 \mu \mathrm{M}$ BA obtained an average multiplication rate of 6.2 shoots per explant with seven blackberries cultivars in six subcultures (Oliveira et al., 2008), and, in a similar protocol with the same BA concentration for four raspberry cultivars, the average multiplication rate was 4.6 (Oliveira and Nino, 2009).

The concentration of $5 \mu \mathrm{M}$ BA also provided the greatest shoot growth in both subcultures (Tab. 1 and 2). However, this plant growth regulator did not influence the number of leaves formed by shoots in the first subculture alone; the response was different in the second one, where the absence of the regulator did not allow for the formation of new shoots. For the 'Xavante' blackberry, $3.56 \mu \mathrm{M}$ BA promoted the number of leaves and the height of the shoots (Pasa et al., 2012).

The absence of growth regulators, as well the presence of BA alone, did not induce callus formation, but, when the culture medium was supplemented with IBA, there was a high callus percentage considering the first subculture (Tab. 1). However, in the second subculture, there was no callus formation in any of the treatments. In a study with 32 different Rubus genotypes that tested BA, zeatin, and kinetin for micropropagation, it was found that both kinetin and zeatin induced callus formation, but failed to promote shoot multiplication or shoot elongation. BA was effective in the promotion of shoot development across the wide range of genotypes used in this study. The lower concentration of BA $(4.4 \mu \mathrm{M})$ worked for most hybrid berries, boysenberries $(R$. idaeus $\times R$. ursinus), some raspberries ( $R$. idaeus) and blackberries during in vitro propagation trials. Tripling the BA concentration $(13.31 \mu \mathrm{M})$ promoted shoot development in the more recalcitrant Rubus cultivars and selections (Wu et al., 2009). This concentration, $4.4 \mu \mathrm{M} \mathrm{BA}$, was also the best one for multiplication of blackberry $(R$. glaucos), with 7.5 shoots per explant (Sigarroa-Rieche and García-Delgado, 2011).

In a trial with $\mathrm{BA}, 2 \mathrm{iP}$ and zeatin, it was also observed that a culture medium supplemented with BA was better for the multiplication of 'Xavante' blackberry and 'Batum' raspberry with 13 and $12 \mu \mathrm{M}$, respectively, but, for improving the shoot height, zeatin and 2iP were more efficient (Leitzke et al., 2010).

There was no hyperhydricity when the medium culture was free of growth regulators or when it was supplemented with only IBA. When BA was used alone, the hyperhydricity was very high, more than $81 \%$ in the first subculture (Tab. 1). This problem was drastically reduced with the increased IBA concentration. In the second subculture, the effect of BA was decreased by half, but was still observable (Tab. 2). This reduction may have occurred because the better plants were selected for the second subculture. Moreover, Oliveira et al. (2008) observed that hyperhydricity increased in every subculture in seven cultivars of blackberry for six subcultures. 
Table 1. Number of shoots, greater shoot height, leaves per shoot, percentage of explants with callus formation, hyperhydricity, rooting, mortality, and number of roots of Rubus erythroclados explants treated with different concentrations of IBA and BA in the first subculture.

\begin{tabular}{|c|c|c|c|c|}
\hline \multirow{2}{*}{$\frac{\text { IBA }}{(\mu \mathrm{M})}$} & \multicolumn{3}{|c|}{$\mathrm{BA}(\mu \mathrm{M})$} & \\
\hline & 0 & 5 & 10 & \\
\hline & \multicolumn{3}{|c|}{ Shoots per explant } & \\
\hline 0 & $1.0 \mathrm{aB}$ & $4.6 \mathrm{aA}$ & $5.6 \mathrm{aA}$ & \\
\hline 3 & $0.2 \mathrm{bB}$ & $2.7 \mathrm{ab}$ & $3.2 \mathrm{bA}$ & \\
\hline 6 & $1.0 \mathrm{aA}$ & $1.6 \mathrm{bA}$ & $1.0 \mathrm{cA}$ & \\
\hline \multirow[t]{2}{*}{ CV (\%) } & \multicolumn{3}{|c|}{20.2} & \\
\hline & \multicolumn{3}{|c|}{ Height of the greatest shoot $(\mathrm{cm})$} & \\
\hline 0 & $0.5 \mathrm{aB}$ & $0.7 \mathrm{aA}$ & $0.5 \mathrm{abB}$ & \\
\hline 3 & $0.0 \mathrm{bB}$ & $0.8 \mathrm{aA}$ & $0.7 \mathrm{aA}$ & \\
\hline 6 & $0.4 \mathrm{aB}$ & $0.7 \mathrm{aA}$ & $0.3 \mathrm{bB}$ & \\
\hline \multirow[t]{2}{*}{ CV (\%) } & \multicolumn{3}{|c|}{6.11} & \\
\hline & \multicolumn{3}{|c|}{ Number of leaves per shoot } & \\
\hline 0 & $1.8 \mathrm{aA}$ & $1.9 \mathrm{aA}$ & $1.8 \mathrm{aA}$ & \\
\hline 3 & $0.4 \mathrm{bB}$ & $1.9 \mathrm{aA}$ & $1.9 \mathrm{aA}$ & \\
\hline 6 & $1.6 \mathrm{aA}$ & $1.9 \mathrm{aA}$ & $1.4 \mathrm{aA}$ & \\
\hline \multirow[t]{2}{*}{ CV (\%) } & \multicolumn{3}{|c|}{19.2} & \\
\hline & \multicolumn{3}{|c|}{ Explants with callus (\%) } & \\
\hline 0 & $0.0 \mathrm{bA}$ & $0.0 \mathrm{cA}$ & $0.0 \mathrm{bA}$ & \\
\hline 3 & $0.0 \mathrm{bB}$ & $41.7 \mathrm{bA}$ & 62.5 aA & \\
\hline 6 & $29.2 \mathrm{aB}$ & $93.7 \mathrm{aA}$ & $6.2 \mathrm{bC}$ & \\
\hline \multirow[t]{2}{*}{ CV $(\%)$} & \multicolumn{3}{|c|}{32.21} & \\
\hline & \multicolumn{3}{|c|}{ Hyperhydricity (\%) } & \\
\hline 0 & $0.0 \mathrm{aB}$ & $91.7 \mathrm{aA}$ & $81.2 \mathrm{aA}$ & \\
\hline 3 & $0.0 \mathrm{aB}$ & $29.2 \mathrm{bA}$ & 43.7 bA & \\
\hline 6 & $0.0 \mathrm{aB}$ & $10.4 \mathrm{cA}$ & $0.0 \mathrm{cB}$ & \\
\hline \multirow[t]{2}{*}{ CV (\%) } & \multicolumn{3}{|c|}{19.8} & \\
\hline & \multicolumn{3}{|c|}{ Rooting (\%) } & \\
\hline 0 & $22.9 \mathrm{bA}$ & $0.0 \mathrm{aB}$ & $2.1 \mathrm{bB}$ & \\
\hline 3 & $68.7 \mathrm{aA}$ & $0.0 \mathrm{aB}$ & $0.0 \mathrm{bB}$ & \\
\hline 6 & $35.4 \mathrm{bA}$ & $0.0 \mathrm{aB}$ & $50.0 \mathrm{aA}$ & \\
\hline \multirow[t]{2}{*}{ CV (\%) } & \multicolumn{3}{|c|}{34.4} & \\
\hline & \multicolumn{3}{|c|}{ Number of roots per explant } & \\
\hline 0 & $1.3 \mathrm{bA}$ & $0.0 \mathrm{aB}$ & $0.5 \mathrm{bB}$ & \\
\hline 3 & $4.2 \mathrm{aA}$ & $0.0 \mathrm{aB}$ & $0.0 \mathrm{bB}$ & \\
\hline 6 & $5.2 \mathrm{aA}$ & $0.0 \mathrm{aB}$ & $4.3 \mathrm{aA}$ & \\
\hline \multirow[t]{2}{*}{ CV (\%) } & \multicolumn{3}{|c|}{15.7} & \\
\hline & \multicolumn{3}{|c|}{ Mortality (\%) } & Average \\
\hline 0 & 52.1 & 8.3 & 14.6 & $25.0 \mathrm{~b}$ \\
\hline 3 & 31.2 & 18.7 & 31.2 & $27.1 \mathrm{ab}$ \\
\hline 6 & 64.6 & 27.1 & 41.7 & $44.4 \mathrm{a}$ \\
\hline Average & $49.3 \mathrm{~A}$ & $18.1 \mathrm{~B}$ & $29.2 \mathrm{~B}$ & \\
\hline CV (\%) & \multicolumn{4}{|c|}{39.4} \\
\hline
\end{tabular}

Means followed by the same lower case letter in the column and capital letter in the row do not differ statistically according to the Tukey test $(P \leq 0.05)$. 
Table 2. Number of shoots, greater shoot height $(\mathrm{cm})$, leaves per shoot, percentage of explants with callus formation, hyperhydricity, rooting, mortality, and number of roots of Rubus erythroclados explants treated with different concentrations of IBA and BA in the second subculture.

\begin{tabular}{|c|c|c|c|c|}
\hline IBA & \multicolumn{3}{|c|}{$\mathrm{BA}(\mu \mathrm{M})$} & \\
\hline$(\mu \mathrm{M})$ & 0 & 5 & 10 & \\
\hline \multicolumn{5}{|c|}{ Shoots per explant } \\
\hline 0 & $0.0 \mathrm{aC}$ & $4.1 \mathrm{aA}$ & $1.7 \mathrm{aB}$ & \\
\hline 3 & $0.0 \mathrm{aB}$ & $2.5 \mathrm{abA}$ & $3.2 \mathrm{aA}$ & \\
\hline 6 & $0.0 \mathrm{aB}$ & $1.3 \mathrm{bA}$ & $0.0 \mathrm{bB}$ & \\
\hline CV (\%) & & 22.7 & & \\
\hline \multicolumn{5}{|c|}{ Height of the greatest shoot $(\mathrm{cm})$} \\
\hline 0 & $0.0 \mathrm{aB}$ & $1.1 \mathrm{aA}$ & $0.7 \mathrm{aA}$ & \\
\hline 3 & $0.0 \mathrm{aB}$ & $0.8 \mathrm{abA}$ & $0.9 \mathrm{aA}$ & \\
\hline 6 & $0.0 \mathrm{aB}$ & $0.6 \mathrm{bA}$ & $0.0 \mathrm{bB}$ & \\
\hline CV (\%) & & 11.3 & & \\
\hline \multicolumn{5}{|c|}{ Number of leaves per shoot } \\
\hline 0 & $0.0 \mathrm{aB}$ & $4.8 \mathrm{abA}$ & $4.0 \mathrm{aA}$ & \\
\hline 3 & $0.0 \mathrm{aB}$ & $5.4 \mathrm{aA}$ & $5.7 \mathrm{aA}$ & \\
\hline 6 & $0.0 \mathrm{aB}$ & $3.4 \mathrm{bA}$ & $0.0 \mathrm{bB}$ & \\
\hline \multirow{2}{*}{\multicolumn{5}{|c|}{$\frac{19.8}{\text { Explants with callus (\%) }}$}} \\
\hline & & & & \\
\hline 0 & 0.0 & 0.0 & 0.0 & \\
\hline 3 & 0.0 & 7.5 & 0.0 & \\
\hline 6 & 0.0 & 0.0 & 0.0 & \\
\hline CV (\%) & & 95.0 & & \\
\hline \multicolumn{5}{|c|}{ yperhydricity (\%) } \\
\hline 0 & $0.0 \mathrm{aB}$ & $35.4 \mathrm{aA}$ & 43.7 aA & \\
\hline 3 & $0.0 \mathrm{aB}$ & $14.6 \mathrm{aB}$ & $50.0 \mathrm{aA}$ & \\
\hline 6 & $0.0 \mathrm{aA}$ & $8.3 \mathrm{aA}$ & $0.0 \mathrm{bA}$ & \\
\hline \multirow{2}{*}{\multicolumn{5}{|c|}{$\frac{62.3}{\text { Rooting (\%) }}$}} \\
\hline & & & & \\
\hline 0 & $0.0 \mathrm{bA}$ & $0.0 \mathrm{aA}$ & $0.0 \mathrm{aA}$ & \\
\hline 3 & $8.5 \mathrm{aA}$ & $0.0 \mathrm{aB}$ & $0.0 \mathrm{aB}$ & \\
\hline 6 & $0.0 \mathrm{bA}$ & $0.0 \mathrm{aA}$ & $0.0 \mathrm{aA}$ & \\
\hline CV (\%) & & 2.3 & & \\
\hline \multicolumn{5}{|c|}{ r of roots per explant } \\
\hline 0 & $0.0 \mathrm{bA}$ & $0.0 \mathrm{aA}$ & $0.0 \mathrm{aA}$ & \\
\hline 3 & $4.0 \mathrm{aA}$ & $0.0 \mathrm{aB}$ & $0.0 \mathrm{aB}$ & \\
\hline 6 & $0.0 \mathrm{bA}$ & $0.0 \mathrm{aA}$ & $0.0 \mathrm{aA}$ & \\
\hline CV (\%) & & 14.0 & & \\
\hline \multicolumn{4}{|c|}{ ty $(\%)$} & Average \\
\hline 0 & 100.0 & 33.3 & 56.2 & $63.2 \mathrm{ab}$ \\
\hline 3 & 91.5 & 25.2 & 33.3 & $50.0 \mathrm{~b}$ \\
\hline 6 & 100.0 & 60.4 & 100.0 & $86.8 \mathrm{a}$ \\
\hline Average & $97.2 \mathrm{~A}$ & $39.6 \mathrm{~B}$ & $63.2 \mathrm{~B}$ & \\
\hline CV (\%) & \multicolumn{4}{|c|}{31.97} \\
\hline
\end{tabular}

Means followed by the same lower case letter in the column and capital letter in the row do not differ statistically according to the Tukey test $(P \leq 0.05)$. 
The concentration of $3 \mu \mathrm{M}$ IBA when used alone provided the highest percentage of rooting $(68.7 \%)$ in the first subculture (Tab. 1). This concentration also provided one of the greater number of roots per explant, around 4, in both subcultures (Tab. 1 and 2). In the second subculture, rooting was absent; with only $3 \mu \mathrm{M}$ IBA, few rooted plants were found. The mortality was higher in the second subculture, mainly with the treatments without BA, where almost all of the explants died (Tab. 2). The beneficial effects of BA may be due to the fact that cytokinins promote cell division, elongation and differentiation and are also responsible for delaying the senescence of plants (Taiz and Zeiger, 2013).

The increased mortality and decreased rooting in the second subculture may be related to the nutritional requirements of this species. In a future phase, the optimization of the mineral composition of the culture medium should be studied to improve the growth of $R$. erythroclados. High quality shoots were obtained for red raspberry with higher concentrations of $\mathrm{CaCl}_{2}, \mathrm{MgSO}_{4}$, and $\mathrm{KH}_{2} \mathrm{PO}_{4}$ in an MS medium (Poothong and Reed, 2015).

\section{Rooting}

The ex vitro rooting of $R$. erythroclados (Fig. 2E, 2F, 2G and $2 \mathrm{H}$ ) was more efficient when compared to the in vitro rooting (Fig. 2A, 2B, 2C and 2D). High rooting percentages were found in the control without IBA, 89.6 and $95.8 \%$ (Tab. 3 and 4). The percentage of rooted plants increased with the in vitro IBA treatment, but achieved less than half with the ex vitro rates. In this case, when IBA was diluted in ethanol, the use of higher concentrations decreased the rooting percentage (Tab. 3), and, when it was diluted in $\mathrm{NaOH}$, the concentrations did not differ (Tab. 4). The dilution of IBA in $\mathrm{NaOH}$ or ethanol did not present differences in the cutting propagation of olives (Oliveira et al., 2009).

The mortality of the microcuttings was significantly lower when the cuttings were placed on the environment ex vitro, only 2.1 and $6.2 \%$ in the control of both trials (Tab. 3 and 4). It was observed that the mortality of the microcuttings increased with the IBA concentration when this growth regulator was diluted in ethanol with 4.92 and $7.38 \mathrm{mM}$ (Tab. 3).

Callus formation was not observed in any ex vitro plant as observed with blackberry after five minutes of immersion and ex vitro rooting (Pelizza et al., 2013). The callus formation reached $58.3 \%$ in vitro with IBA diluted in ethanol (Tab. 3), but only $4.2 \%$ when IBA was diluted in $\mathrm{NaOH}$. This result could indicate that the salts that make up the culture medium may affect cell differentiation and change the morphogenetic
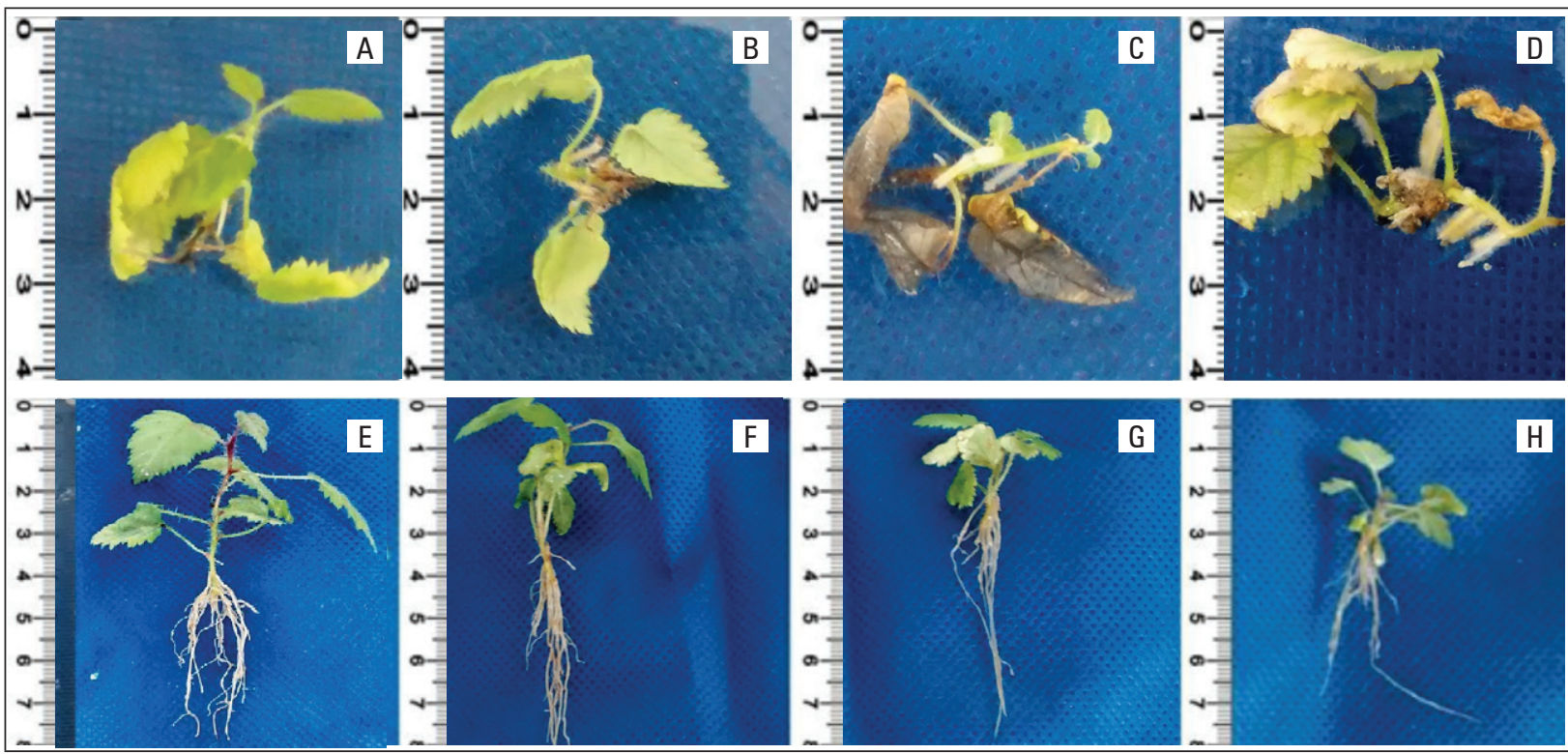

G

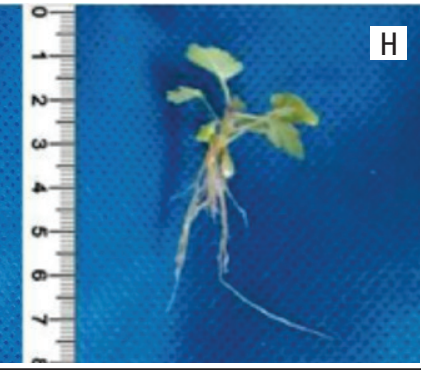

Figure 2. Aspect of Rubus erythroclados microcuttings under different IBA pulse treatments diluted in NaOH. A, B, C, D: cultivated in vitro and treated with $0,2.46,4.92$ and $7.38 \mathrm{mM}$ IBA, respectively. E, F, G, H: cultivated ex vitro and treated with $0,2.46,4.92$ and $7.38 \mathrm{mM}$ IBA, respectively. 
Table 3. Rooting, length of the highest root, number of leaves per plant, mortality, percentage of callus formation, number of roots per microcutting, growth and number of leaves per Rubus erythroaclados plant treated with different concentrations of IBA diluted in ethanol $(50 \% \mathrm{v} / \mathrm{v})$ and placed in and ex vitro.

\begin{tabular}{|c|c|c|c|c|c|}
\hline & \multicolumn{4}{|c|}{ IBA (mM) } & \\
\hline & 0 & 2.46 & 4.92 & 7.38 & \\
\hline & \multicolumn{4}{|c|}{ Rooting $(\%)^{(1)}$} & \\
\hline In vitro & $0.0 \mathrm{bC}$ & $41.7 \mathrm{bA}$ & $14.6 \mathrm{bB}$ & $39.6 \mathrm{aA}$ & \\
\hline Ex vitro & $95.8 \mathrm{aA}$ & $89.6 \mathrm{aAB}$ & $64.6 \mathrm{aB}$ & $39.6 \mathrm{aC}$ & \\
\hline \multirow[t]{2}{*}{ CV (\%) } & \multicolumn{4}{|c|}{11.9} & \\
\hline & \multicolumn{4}{|c|}{ Largest root length $(\mathrm{cm})$} & \\
\hline In vitro & $0.0 \mathrm{bB}$ & $0.6 \mathrm{bA}$ & $0.5 \mathrm{bA}$ & $0.5 \mathrm{bA}$ & \\
\hline Ex vitro & $3.1 \mathrm{aAB}$ & $3.3 \mathrm{aA}$ & $2.7 \mathrm{aAB}$ & $2.4 \mathrm{aB}$ & \\
\hline \multirow[t]{2}{*}{ CV (\%) } & \multicolumn{4}{|c|}{7.1} & \\
\hline & \multicolumn{4}{|c|}{ Mortality (\%) } & \\
\hline In vitro & $89.6 \mathrm{aA}$ & $39.6 \mathrm{aC}$ & $77.1 \mathrm{aAB}$ & $47.9 \mathrm{aBC}$ & \\
\hline Ex vitro & $2.1 \mathrm{bB}$ & $8.3 \mathrm{bB}$ & $35.4 \mathrm{bA}$ & $58.3 \mathrm{aA}$ & \\
\hline \multirow[t]{2}{*}{ CV (\%) } & \multicolumn{4}{|c|}{16.8} & \\
\hline & \multicolumn{4}{|c|}{ Callus formation (\%) } & \\
\hline In vitro & $0.0 \mathrm{aC}$ & $58.3 \mathrm{aA}$ & $22.9 \mathrm{aB}$ & $52.1 \mathrm{aA}$ & \\
\hline Ex vitro & $0.0 \mathrm{aA}$ & $0.0 \mathrm{bA}$ & $0.0 \mathrm{bA}$ & $0.0 \mathrm{bA}$ & \\
\hline \multirow[t]{2}{*}{ CV (\%) } & \multicolumn{4}{|c|}{32.9} & \\
\hline & \multicolumn{4}{|c|}{ Roots per microcutting } & Average \\
\hline In vitro & 0.0 & 4.5 & 5.2 & 4.2 & $3.5 \mathrm{~b}$ \\
\hline Ex vitro & 4.6 & 12.5 & 7.9 & 10.7 & $8.9 \mathrm{a}$ \\
\hline Average & $2.3 \mathrm{~B}$ & $8.5 \mathrm{~A}$ & $6.5 \mathrm{~A}$ & $7.4 \mathrm{~A}$ & \\
\hline \multirow[t]{2}{*}{ CV (\%) } & \multicolumn{5}{|c|}{25.4} \\
\hline & \multicolumn{4}{|c|}{ Plant growth $(\mathrm{cm})$} & Average \\
\hline In vitro & 0.1 & 0.1 & 0.0 & 0.0 & $0.1 \mathrm{~b}$ \\
\hline Ex vitro & 0.8 & 0.6 & 0.2 & 0.3 & $0.5 \mathrm{a}$ \\
\hline Average & $0.4 \mathrm{~A}$ & $0.4 \mathrm{~A}$ & $0.1 \mathrm{~A}$ & $0.1 \mathrm{~A}$ & \\
\hline \multirow[t]{2}{*}{ CV (\%) } & \multicolumn{5}{|c|}{13.8} \\
\hline & \multicolumn{4}{|c|}{ Leaves per plant } & Average \\
\hline In vitro & 1.2 & 0.5 & 0.1 & 0.0 & $0.4 \mathrm{~b}$ \\
\hline Ex vitro & 3.1 & 1.4 & 0.7 & 0.2 & $1.3 \mathrm{a}$ \\
\hline Average & $2.1 \mathrm{~A}$ & $0.9 \mathrm{~B}$ & $0.4 \mathrm{BC}$ & $0.1 \mathrm{C}$ & \\
\hline CV (\%) & \multicolumn{5}{|c|}{19.6} \\
\hline
\end{tabular}

Means followed by the same lower case letter in the column and capital letter in the row do not differ statistically according to the Tukey test $(P \leq 0.05)$.

route, leading to higher callus formation than in roots. Leitzke et al. (2009) observed that the MS medium provided a lower rooting rate and lower number and length of roots than WPM with in 'Xavante' blackberry. Welander (1985), Del Castillo and Zerda (1990) obtained 100\% Rubus spp. rooting in vitro by removing $1 / 5$ of the $\mathrm{MS}$ macronutrients and adding $0.05 \mu \mathrm{M}$ IBA. Other auxins should be tested, such as naphthalene acetic acid (NAA), which showed good results for blackberries (Villa et al., 2008).
The number of roots was also higher ex vitro in both methods of dilution. The IBA concentrations did not differ from each other, but they were higher than the control. The number of 'Xavante' blackberry roots also increased with IBA, up to $1.6 \mathrm{mM}$ during the ex vitro rooting (Pelizza et al., 2013). Besides the number of roots, their length was also higher ex vitro. The absence of the growth regulator promoted the same root length as the other treatments ex vitro diluted with ethanol (Tab. 3). When the dilution was 


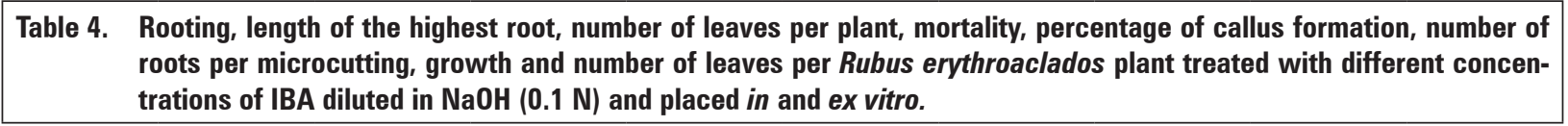

\begin{tabular}{|c|c|c|c|c|c|}
\hline & \multicolumn{4}{|c|}{$\mathrm{IBA}(\mathrm{mM})$} & \\
\hline & 0 & 2.46 & 4.92 & 7.38 & \\
\hline & \multicolumn{4}{|c|}{ Rooting (\%) } & \\
\hline In vitro & $6.2 \mathrm{bC}$ & $10.4 \mathrm{bBC}$ & $22.9 \mathrm{bAB}$ & $39.6 \mathrm{bA}$ & \\
\hline Ex vitro & 89.6 aA & $97.9 \mathrm{aA}$ & $87.5 \mathrm{aA}$ & $89.6 \mathrm{aA}$ & \\
\hline \multirow[t]{2}{*}{ CV (\%) } & \multicolumn{4}{|c|}{14.7} & \\
\hline & \multicolumn{4}{|c|}{ Largest root length $(\mathrm{cm})$} & \\
\hline In vitro & $0.8 \mathrm{bA}$ & $0.4 \mathrm{bA}$ & $0.7 \mathrm{bA}$ & $0.8 \mathrm{bA}$ & \\
\hline Ex vitro & $3.1 \mathrm{aA}$ & $3.8 \mathrm{aA}$ & $4.3 \mathrm{aA}$ & $3.2 \mathrm{aA}$ & \\
\hline \multirow[t]{2}{*}{ CV (\%) } & \multicolumn{4}{|c|}{24.8} & \\
\hline & \multicolumn{4}{|c|}{ Mortality (\%) } & Average \\
\hline In vitro & 60.4 & 87.5 & 75.0 & 54.2 & $69.3 \mathrm{a}$ \\
\hline Ex vitro & 6.2 & 2.1 & 8.3 & 4.2 & $5.2 b$ \\
\hline Average & $4.8 \mathrm{~A}$ & $5.3 \mathrm{~A}$ & $5.5 \mathrm{~A}$ & $4.5 \mathrm{~A}$ & \\
\hline \multirow[t]{2}{*}{ CV (\%) } & \multicolumn{4}{|c|}{28.3} & \\
\hline & \multicolumn{4}{|c|}{ Callus formation $(\%)^{\text {ns }}$} & \\
\hline In vitro & 0.0 & 0.0 & 4.2 & 2.1 & \\
\hline Ex vitro & 0.0 & 0.0 & 0.0 & 0.0 & \\
\hline \multirow[t]{2}{*}{ CV (\%) } & \multicolumn{4}{|c|}{66.2} & \\
\hline & \multicolumn{4}{|c|}{ Roots per microcutting } & Average \\
\hline In vitro & 2.0 & 4.2 & 6.2 & 6.9 & $4.8 \mathrm{~b}$ \\
\hline Ex vitro & 5.3 & 8.4 & 6.3 & 8.7 & $7.2 \mathrm{a}$ \\
\hline Average & $3.6 \mathrm{~B}$ & $6.3 \mathrm{AB}$ & $6.2 \mathrm{AB}$ & $7.8 \mathrm{~A}$ & \\
\hline \multirow[t]{2}{*}{ CV (\%) } & \multicolumn{4}{|c|}{18.1} & \\
\hline & \multicolumn{4}{|c|}{ Plant growth $(\mathrm{cm})$} & \\
\hline In vitro & $0.3 \mathrm{aAB}$ & $0.0 \mathrm{bB}$ & $0.2 \mathrm{aAB}$ & $0.4 \mathrm{aA}$ & \\
\hline Ex vitro & $0.7 \mathrm{aA}$ & $0.9 \mathrm{aA}$ & $0.4 \mathrm{aA}$ & $0.8 \mathrm{aA}$ & \\
\hline \multirow[t]{2}{*}{ CV (\%) } & \multicolumn{4}{|c|}{12.9} & \\
\hline & \multicolumn{4}{|c|}{ Leaves per plant } & \\
\hline In vitro & $2.8 \mathrm{aA}$ & $0.0 \mathrm{bB}$ & $1.6 \mathrm{aA}$ & $2.0 \mathrm{aA}$ & \\
\hline Ex vitro & $2.8 \mathrm{aAB}$ & $3.4 \mathrm{aA}$ & $1.3 \mathrm{aB}$ & $2.0 \mathrm{aAB}$ & \\
\hline CV $(\%)$ & \multicolumn{4}{|c|}{20.0} & \\
\hline
\end{tabular}

Means followed by the same lower case letter in the column and capital letter in the row do not differ statistically according to the Tukey test $(P \leq 0.05)$. ns: not significant.

in $\mathrm{NaOH}$, the growth regulator did not influence the root growth length (Tab. 4). Leitzke et al. (2009) observed that, when increasing the IBA concentration, there was a reduction in the root length of blackberries and raspberries.

In general, the ex vitro rooting formed higher plants with more new leaves, but the highest IBA concentrations (4.92 and $7.38 \mathrm{mM}$ ) were detrimental to the growth when IBA was diluted in ethanol (Tab. 3).

The high rates of rooting ex vitro in the absence of growth regulators show that this technique is promising for the species in question and that in vitro rooting is not suitable. Thus, the in vitro multiplication and ex vitro rooting and acclimatization of the greenberry are recommended.

\section{CONCLUSIONS}

An efficient and simple protocol can be used for $R$. erythroclados micropropagation with $5 \mu \mathrm{M}$ BA for in vitro shoot proliferation and ex vitro rooting of microcuttings using intermittent misting without the addition of a growth regulator. 


\section{ACKNOWLEDGEMENTS}

The authors thank the CAPES (Coordenação de Aperfeiçoamento de Pessoal de Nível Superior) and CNPq (Conselho Nacional de Desenvolvimento Científico e Tecnológico) for financial support via research scholarships that were granted to the first and second authors, respectively.

Conflict of interests: the manuscript was prepared and reviewed with the participation of the authors, who declare that there exists no conflict of interest that puts the validity of the presented results at risk.

\section{BIBLIOGRAPHIC REFERENCES}

Augusto, C.S.S., L.A. Biasi, and C.A. Telles. 2006. Enraizamento e aclimatização de plantas micropropagadas de amoreira-preta cv. Brazos. Rev. Bras. Frutic. 28(3), 473476. Doi: 10.1590/S0100-29452006000300029

Campagnolo, M.A. and R. Pio. 2012. Enraizamento de estacas caulinares e radiculares de cultivares de amoreira - preta coletadas em diferentes épocas, armazenadas a frio e tratadas com IBA. Ciênc. Rural 42, 232-237. Doi: 10.1590/S0103-84782012000200008

Clapa, D., A. Fira and N. Joshee. 2013. An efficient ex vitro rooting and acclimatization method for horticultural plants using float hydroculture. HortScience 48(9), 1159-1167.

Cordeiro, J., C.V. Roderjan, and W.A. Rodrigues. 2011. Plantas lenhosas da floresta ombrófila mista do parque municipal das Araucárias - Guarapuava (PR). Ambiência 7, 441-460. Doi: 10.5777/ambiencia.2011.03.03

Debnath, S.C. 2003. Micropropagation of small fruits. pp. 465-506. In: Jain, S.M. and K. Ishii (eds.). Micropropagation of woody trees and fruits. Kluwer Academic Publishers, Dordrecht, The Netherlands. Doi: 10.1007/978-94-010-0125-0_15

Debnath, S.C. 2004. Clonal propagation of dwarf raspberry (Rubus pubescens Raf.) through in vitro axillary shoot proliferation. Plant Growth Reg. 43, 179-186. Doi: 10.1023/B:GROW.0000040110.53216.6a

Del Castillo, A.R. and A.A. Zerda. 1990. Estudios preliminaries para la propagación clonal in vitro de mora $(R u$ bus glaucus L.). Agron. Colomb. 7(1-2), 17-25.

Deng, R. and D.J. Donnelly. 1993. In vitro hardening of red raspberry through $\mathrm{CO}_{2}$ enrichment and relative humidity reduction on sugar-free medium. Can. J. Plant Sci. 73(4), 1105-1113. Doi: 10.4141/cjps93-149

Erig, A.C., A. De Rossi, and G.R.L. Fortes. 2002. 6-benzilaminopurina e ácido indolbutírico na multiplicação in vitro da amoreira-preta (Rubus idaeus), cv.
Tupy. Ciênc. Rural 32(5), 765-770. Doi: 10.1590/ S0103-84782002000500005

Jin, W., Y. Gu, and S.Z. Zhen. 1992. In vitro propagation of Rubus species. Sci. Hortic. 49(3-4), 335-340. Doi. 10.1016/0304-4238(92)90169-D

Lazic, T. and D. Ruzic. 2007. Organogenesis in vitro from the leaf of blackberry cv. Cacanska Bestrna. Genetika 39, 69-78. Doi: 10.2298/GENSR0701069L

Leitzke, L.N., C.R. Damiani, and M.W. Schuch. 2009. Meio de cultura, concentração de AIB e tempo de cultivo no enraizamento in vitro de amoreira-preta e framboeseira. Rev. Bras. Frutic. 31(2), 582-587. Doi: 10.1590/ S0100-29452009000200037

Leitzke, L.N., C.R. Damiani, and M.W. Schuch. 2010. Influência do meio de cultura, tipo e concentração de citocininas na multiplicação in vitro de amoreira-preta e framboeseira. Ciênc Agrotec. 34(2), 352-360. Doi: 10.1590/S1413-70542010000200012

Maia, A.J. and R.V. Botelho. 2008. Reguladores vegetais no enraizamento de estacas lenhosas da amoreira-preta cv. Xavante. Semina: Ciênc. Agrár. 29, 323-330. Doi: 10.5433/1679-0359.2008v29n2p323

Murashige, T. and F. Skoog. 1962. A revised medium for rapid growth and bio assays with tobacco tissue cultures. Physiol. Plant 15, 473-479. Doi: 10.1111/j.1399. 3054.1962.tb08052.x

Oliveira, A.F., N.N.J. Chalfun, A.A. Alvarenga, J. Vieira Neto, R. Pio, and D.L. Oliveira. 2009. Estaquia de oliveira em diferentes épocas, substratos e doses de AIB diluído em NaOH e álcool. Ciênc. Agrotec. 33(1), $79-$ 85. Doi: 10.1590/S1413-70542009000100011

Oliveira, R.P. and A.F.P. Nino. 2009. Potencial de multiplicação in vitro de cultivares de framboeseira. Rev. Bras. Frutic. 31(1), 280-284. Doi: 10.1590/ S0100-29452009000100040

Oliveira, R.P., A.F.P. Nino, and L.V. Ferreira. 2008. Potencial de multiplicação in vitro de cultivares de amoreira -preta. Rev. Bras. Frutic. 30(3), 585-589. Doi: 10.1590/ S0100-29452008000300004

Pasa, M.S., G.L. Carvalho, M.W. Schuch, J.D. Schmitz, M.M. Torchelsen, G.K. Nickel, L.R. Sommer, T.S. Lima, and S.S. Camargo. 2012. Qualidade de luz e fitorreguladores na multiplicação e enraizamento in vitro da amoreira-preta 'Xavante'. Ciênc. Rural 42(8), 1392-1396. Doi: 10.1590/S0103-84782012000800010

Pelizza, T.R., J. Muniz, P. Camargo, A.A. Kretzschmar, and L. Rufato. 2013. Enraizamento ex vitro e aclimatização de plântulas micropropagadas de amoreira-preta 'Xavante'. Rev. Bras. Frutic. 35(1), 329-332. Doi: 10.1590/S0100-29452013000100039

Poothong, S. and B.M. Reed. 2015. Increased $\mathrm{CaCl}_{2}, \mathrm{MgSO}_{4}$, and $\mathrm{KH}_{2} \mathrm{PO}_{4}$ improve the growth of micropropagated red raspberries. In Vitro Cell Dev. Biol-Plant 51, 648658. Doi: 10.1007/s11627-015-9720-y 
Sigarroa-Rieche, A.K. and C.L. García-Delgado. 2011. Establecimiento y multiplicación in vitro de mora de castilla (Rubus glaucus Benth) variedade sin espinas, mediante ápices meristemáticos. Acta Agron. 60(4), 347-354.

Taiz, L. and E. Zeiger. 2013. Fisiologia vegetal. $5^{\text {th }}$ ed. Artmed, Porto Alegre, Brazil.

Villa, F., M. Pasqual, F.A. Assis, L.A.S. Pio, and G.A. Assis. 2008. Crescimento in vitro de amoreira-preta: efeito de reguladores de crescimento e da cultivar. Ciênc. Agrotec. 32(6), 1754-1759. Doi: 10.1590/S1413-70542008000600012

Welander, M. 1985. In vitro culture of raspberry (Rubus idaeus) for mass propagation. J. Hortic. Sci. 60(4), 493499. Doi: 10.1080/14620316.1985.11515656

Wu, J., S.A. Miller, H.K. Hall, and P.A. Mooney. 2009. Factors affecting the efficiency of micropropagation from lateral buds and shoot tips of Rubus. Plant Cell Tiss. Org. 99, 17-25. Doi: 10.1007/s11240-009-9571-5 